\title{
Understanding Learning Styles in Order to Meet Educational Objectives
}

\section{By John E. Ford}

$\mathrm{P}$ robably no industry has perpetuated the myth of slow-to-change and reluctant-to-embrace new ideas and technologies than the agricultural sector. Within agriculture, ranching is the segment most perceived to be "set-in-its-ways." In part, this is because ranching families with long histories in beef production are committed to ranching not only as a livelihood but also as a way to preserve family heritage and traditions. Undoubtedly that very respect for tradition gives the perception that change is slow to occur in the ranching community where the retention of traditional practices are often viewed as outdated even when efficient and fully profitable.

Nonetheless, few businesses have made the advances witnessed in beef production over the past half century. Changes in operation methodologies, growth of feedlots and the feeding industry, and use of Expected Progeny Differences (EPDs) and DNA-based biotechnology provide compelling examples. These changes have not come easily. Of course, change often does not come easily in most established industries. History is littered with the past remains or memories of businesses that, for whatever reason, did not change or were slow to change in response to innovation, new markets, production differentiation and consumer desires, and more nimble and/or less risk averse competitors. For example, one should consider Montgomery Ward, the retail giant of the early to mid-20th century. This mail-order "department store" was a success by marketing a large selection of goods to rural America, yet was unable to respond to changing consumer demands or the pressure of its competitors as America became a more mobile urban populace. ${ }^{1}$

How does change come about? Change in business comes from a need, real or perceived. The need can be internal to a ranch and its operations, such as the desire to see increased

This article has been peer reviewed. calf weaning weights. Likewise, the need might arise from external pressures, such as consumer demands for a more uniform, consistent product. Regardless, addressing needs invariably initiates research, experimentation, education, and finally change or implementation. Although all of the aforementioned steps are important in realizing positive change in the ranch environment, education could very well be the key component. Changed practices must be understood from the technical, practical, and financial standpoint before successful incorporation into a production or management setting.

\section{The Role of Education in Ranching}

Education is more than an agent of change on the "production line." Education is essential for the development, maintenance, and growth of the value of human capital. Edward Prewitt cites research indicating that pay is not the most critical factor in employee satisfaction. ${ }^{2}$ Rather, the opportunity to learn and use new skills is much more important in attracting, retaining and motivating employees. Marilyn Mahugh states, "Continuous professional development is part of what makes up a rewarding work environment." (p. 2) Those businesses that remain competitive in today's quickly changing world are those entities that realize their workforce, in addition to their products or services, provide the competitive edge and financial success. Providing opportunities for employee learning, development, and growth contributes to improved individual and organizational performance.

Today, there are no shortages of learning opportunities for those involved in the ranching industry. The "information age" has broken down barriers from rural and remote settings such that isolation is no longer a hindrance to continuing education. Utilization of internet websites and subscriptions to industry publications bring information directly to the ranch, home, or office regardless of the zip code. State cooperative extension services, USDA Natural Resources Con- 
servation Service, universities, and community colleges provide educational opportunities in both a formal and informal setting. Industry-sponsored field days and short courses also can provide timely information on new technologies. Participation in trade and professional organizations allows for an exchange of ideas and information. However, attending or participating or enrolling an employee or managerial decision maker in one of the numerous educational opportunities does not guarantee that the learning and growth perspective of the ranch's management plan will be met.

What are the steps that a ranching enterprise should undertake to foster an atmosphere of learning that contributes to the well being of the ranch and personal and professional growth of its employees? Ranch management has to be committed to the "learning workplace" where continued education is the rule rather than the exception. Ranching is a time-consuming endeavor; however, lack of time is not an acceptable constraint to learning. Allowing employees release time for continuing education is essential. This does not mean that the doctor crew is to be sent to a field day when a load of fresh yearlings is scheduled to arrive. However, they should be encouraged to participate in an educational program after the last load of yearlings has been shipped. Cost should not be a constraint to developing an educational strategy. Funding, or at the least a sharing of training cost, reinforces that the ranch is committed to continuing education. ${ }^{4}$

The first step in formulating a professional development program should be inventorying the knowledge base of the ranch family and workforce. A successful continuing education program is developed after the ranch's strengths, weaknesses, and needs have been identified. The ranch manager must also realize that not all members of the ranch family learn in the same way. We all have different learning styles and the manager that recognizes this constraint can guide the employee to those learning tools and experiences that will best help the ranch meet its goals and enhance professional development. Understanding generational diversity and its implication on adult learning is of key importance.

\section{Generational Learning Styles}

A generation is a group of people who share the same place and time in history. Because of this shared space in time they have experiences in common and a similar view of the world and how things should be. ${ }^{5} \mathrm{~A}$ generation is considered to be approximately 20 years in length. Factors that influence and motivate one generation can be quite different from those that influence and motivate another generation. Today, there are four major generational groups that make up the workforce: Traditionalists are those 65 years and older; Baby Boomers are 46-64 years of age; members of Generation X were born between 1961 and 1981; and lastly Generation Y, sometimes referred to as "Nesters" or "Millenials," were born after 1982. Because the factors that influence and motivate each generation vary, a teaching style or delivery method that successfully conveys its message to a member of the Baby
Boom generation might be quite lost on a member of Generation $\mathrm{X}$. Understanding that generational learning patterns and educational needs differ allows ranch decision makers to develop effective educational strategies.

Traditionalists are loyal and hard working. Their view of the world was formed by events such as the Second World War and Korean War. They have great respect for authority and are detail-oriented. Traditionalists began their careers with the intention of remaining with the same employer until retirement. In their view, changing jobs carries a stigma. ${ }^{6}$ Even though this group and early Baby Boomers are the fastest-growing group of internet users, this generation learns better by interacting directly with people, not through impersonal media such as computers. ${ }^{6}$ Field days, extension educational meetings, and short courses that allow for social interaction in a relaxed atmosphere provide a learning environment that is most comfortable for this generation. Members of this pre-television generation can be widely read; therefore, printed materials that allow for additional review will aid or accelerate the learning process. Accordingly, outreach to this generation might best be met by providing printed material. Trade publications, extension publications, and professional journals are good educational tools for Traditionalists. It is likely that the ranch patriarchs are of this generation. Educational needs might focus around estate management and planning, information that will assist in transitioning the ranch to the next generation.

Baby Boomers were raised in an era of extreme optimism and progress. ${ }^{5}$ They grew up in a post-war, financially stable environment created by Traditionalists. Many are ambitious and driven. Baby Boomers want to succeed. They want to build stellar careers, and this generation considers a job change as a detour in their climb to the top. ${ }^{6}$ Boomers want to be in charge of their learning. They value learning experiences that provide a skill or knowledge that can be integrated into their everyday work. ${ }^{2}$ In other words, the subject matter being taught must have practical value. They enjoy social interaction and want a chance to show what they know. Baby Boomers like a structured approach to learning. Community college courses, extension short courses, field days, and symposia provide Baby Boomers with a structured setting and the opportunity for interaction. Members of this generation are in, or are assuming, managerial roles. Educational needs might center on capital acquisition management, financial planning, or other areas related to growing the ranching enterprise.

The average age of all US principal farm operators in 2002 was 55.3 years of age, with the average age for beef producers being 56.7 years. ${ }^{7}$ These data indicate that the majority of beef producers are Traditionalists or Baby Boomers and therefore many educational opportunities are designed to best engage their learning styles. However, educational programming designed to meet the needs of Traditionalists and Boomers will not necessarily meet the needs of Generation $\mathrm{X}$ and Generation $\mathrm{Y}$.

Members of Generation $X$ formed their view of the world during post-Vietnam and Watergate. ${ }^{5}$ They tend to be in- 
dependent and somewhat cynical. Generation $\mathrm{X}$ views job changing as necessary. ${ }^{6}$ Similar to Baby Boomers, they want information to be specific and geared to practical outcomes. Social interaction with others is not as necessary; they understand technology and expect that it be utilized. They prefer to work independently with self-directed projects. Internet, website, and distance learning provide the type of learning opportunities that best meet the needs of Generation X. Members of Generation X consider reading time consuming; therefore, information from printed material needs to be summarized into bulleted or annotated format.

The youngest members of the workforce, Generation Y, were born into a high-tech world and the use of technology is almost instinctual. This generation considers changing jobs routine. ${ }^{6}$ Learning experiences must be interactive and fast-paced. As students, Generation Y members require frequent and instantaneous feedback. This newest work force generation is adept at multi-tasking; however, many members lack people or socialization skills. Surprisingly, Generation $\mathrm{Y}$ members are readers and will take the time to re-enforce knowledge learned through another process. As would be expected, internet and website, interactive, and hands-on learning best suit members of Generation Y. However, short attention spans require that learning opportunities be supervised, structured, and fast-paced. This is the 30-second sound-bite generation geared to information uptake on the scale of a television commercial.

Due to their age, Generations $\mathrm{X}$ and $\mathrm{Y}$ are probably the most familiar with the day-to-day field operations of the ranch, and are looked to for production-related decisions, and are often expected to assist with labor. Educational needs focusing on increased production (forage, beef, and wildlife) or management tools that lead to an increase in production might best fit the learners and the ranch's overall needs.

\section{Educational Strategies for Ranches}

Regardless of the generation, adult learners retain what is relevant to them and what they need to be successful at their job. Adults are motivated to learn if they see where new knowledge can be applied. ${ }^{8}$ Placing the right member of the ranch staff in the right educational situation is the first step to a successful learning and growth strategy. Communication among coworkers is an important part of the learning and growth perspective. ${ }^{9}$ For the learning and growth perspective to be successful, ranch decision-makers must encourage a free flow of information between coworkers. According to business consultant Nancy Ahlrichs, continuous learning is not sufficient, because employees also must be engaged in continuous teaching. ${ }^{5}$ Communication between co-workers about knowledge obtained at a cooperative extension short course not only expands the knowledge base but helps reinforce knowledge learned. In addition to expanding the knowledge base, this communication or teaching helps employees cement the knowledge they have just acquired. Helping a member of the ranch team cement knowledge is as simple as asking them to demonstrate proper vaccination techniques learned at a Beef Quality Assurance program.

\section{Conclusions}

A ranch's learning and growth goals can be set and measured by the number of educational activities and programs attended or the number of practices implemented due to the acquisition of new knowledge. However, developing action items and goals that measure employee satisfaction and motivation in reality have a greater impact on the ranch's bottom line. Adult learning research suggests that the most successful professional development is that which is sustained over time. Setting a goal to implement a program to review yearly professional development and its impact on ranch practices sends the message that members of the ranch family are valued team members and workplace growth is an expectation. By doing so, continuous education becomes the normative practice, employee satisfaction level remains high, and the ranch has the most current and relevant information, insuring that it has the tools in place to remain a competitive enterprise.

Author is County Extension Agent-Agriculture, PO Box 1119, Kingsville, TX 78363, je-ford@tamu.edu.

\section{References}

1. Guy, S. 2000. End of line for Ward stores, Chicago institution is closing after 128 years; 37,000 lose jobs. Chicago Sun-Times p 33, December 29.

2. Prewitt, E. 1999. How to keep your company's star employee. In: P. Michelman, L. Gray, and A. Herrin [eds.]. Retaining your best people. Boston, MA: Harvard Business School Press. p 62-69.

3. Mahugh, M. 2004. The Ethic of Lifelong Learning. Stanford Nurse 24(2): 2.

4. McGrann, J. M., F. DeLans, and D. McCorkle. 1999. Farm and ranch personnel Management. Manhattan, KS: Kansas State University. 4 p.

5. Moore, B., And S. TAylor. 2004. Learning to work with generational diversity. Stanford Nurse 24(2): 3-5.

6. Gleeson, P. B. 2003. Managing and motivating the generations: Implications for the student and the employee. Texas Woman's University and Matrix Rehabilitation. Available at: http://www.uwsp.edu/education/facets/links_resources/4413. pdf. Accessed 6 March 2007.

7. Allen, R., And G. Harris. 2006. What we know about the demographics of U.S. farm operators. Agricultural Outlook Forum 2005. Available at: http://www.nass.usda.gov/census/ census02/otheranalysis/demographicpaper022505.txt. Accessed 6 March 2007.

8. Zемке, R., And S. Zемке. 1984. 30 things we know for sure about adult learners. Innovation Abstracts 6(8):1-4, March 9.

9. Kaplan, R. S., and D. P. Norton. 1996. Learning and growth perspective. In: H. Heimbouch [ed.]. The Balanced Scorecard. Boston, MA: Harvard Business School Press. p 126-146. 